\title{
Observations on Traditional Phytotherapy among the Inhabitants of Lahaul Valley through Amchi System of Medicine-A Cold Desert Area of Himachal Pradesh in North Western Himalayas, India
}

\author{
Parveen Kumar Sharma ${ }^{1}$, Surender Kumar Thakur, S. Manuja, R. K. Rana, Pardeep Kumar, \\ Sanjay Sharma, Jagdish Chand, Ashok Singh, Krishan Kumar Katoch ${ }^{2}$ \\ ${ }^{1}$ Krishi Vigyan Kendra Lahaul and Spiti, Kukumseri, India \\ ${ }^{2}$ Chaudhary Sarwan Kumar Himachal Pradesh Krishi Vishvavidyalaya, Palampur, India \\ E-mail: praveenkumarsharma11@rediffmail.com \\ Received April 1, 2011; revised April 20, 2011; accepted May 5, 2011
}

\begin{abstract}
The paper highlights the Phyto-diversity and indigenous uses an ecosystem existing in Lahaul Valley of tribal district of Lahaul and Spiti in Himacjhal Pradesh, India. This is one of the most preferred tourist spot especially for foreigners. The cold desert area of India is known for its specific topography, sense climate and unique vegetation. The valley is rich in high value medicinal wealth and local inhabitants (Buddhist) practice the Tebetan Amchi System of Medicine. Keeping in view the continuous pressure on nature, this paper reflects the Phyto-diversity of Valley, with reference to medicinal and aromatic plants and conservation mechanisms to protect the valuable wealth of the valley and also suggests effective ecotourisim planning of the study area.
\end{abstract}

Keywords: Diversity, Medicinal and Aromatic Plants, Ecotourisim, Lahaul Valley, Indigenous Uses, Tebetan Amchi System of Medicine

\section{Introduction}

Twenty one year ago the word did not know about the biodiversity. Today, it is one of the most commonly used expressions in the biological sciences and has become a household word. During the National Forum on Biodiversity held at Washington DC, w.e.f. September 21-24, 1986, under the auspices of the National Academy of Science, Smithsonian Institute, the word spread like fire throughout the world. In the Rio Environmental Summit in 1992, biodiversity dominated the central issues of scientific and political concern worldwide. At global level about 16,04,000 species of plants, animals and microorganisms have been described so far. However, it is estimated that there are around 17,98,000 species. Of the total species, 4,22,000 flowering plants reported from the world, of which $>50,000$ species are used for medicinal purpose.

The high altitude Himalaya is rich in endemic plants [1]. The increasing potential threat to biological diversity ia an irreversible environment disorder that warrant im- mediate remedial measures for sustainable conservation of biodiversity. It is believed that the excessive anthropogenic activities are the main cause of decline in population and availability of medicinal and aromatic plants in the Himalayan region [2-5]. The fast pace of tourism in high altitudinal areas are another important factor causing the damage of bio-diverse ecological system [6].

Himalaya is one of the mega biodiversityregion of world [7]. The north western Himalaya consist unique habitats to sustain several endemic and rare plant taxa. The vegetation comprises evergreen forests with pure stands of Pinus roxburghii, Pinus wallichiana, Quercus spp., Cedrus deodara, Abies pindrow, Picea smithiana, Taxus wallichiana and Juniperus spp. in dry temperate and alpine regions representing various species composition make the valleys rich in phytodiversity.

The cold desert area covers 35 per cent of the total geographical area in Himachal Pradesh. A review of literature indicates very few studies on medicinal \& aromatic plants and ethnobotany of tribal valley/area of Lahaul and Spiti district of Himachal Pradesh [1,8-13]. 


\section{Materials and Method}

\subsection{Study Area}

The present study has been carried out in Lahaul valley of Himachal Pradesh. The Lahaul valley lies between $31^{\circ} 44^{\prime} 57^{\prime \prime}$ and $32^{\circ} 59^{\prime} 57^{\prime \prime} \mathrm{N}$ latitude and $76^{\circ} 46^{\prime} 29^{\prime \prime}$ and $78^{\circ} 41^{\prime} 34^{\prime \prime} \mathrm{E}$ longitude. It is surrounded by the main Himalayan ranges on the North mainly Baralacha Pass, the mid Himalayan range or Pir Punjal on the South, the Kunjum range which separates Lahaul from Spiti on the East and the off-shoot of the Pir Punjal range on the West. In its West, the Chenab river flows into Pangi valley, while in the North-East the Yunan river flows into Zanskar. The Rohtang Pass (3978 m), the gate way to valley, connects Lahaul to Kullu district. The valley can be approached through Rohtang Pass $(3978 \mathrm{~m})$ by road to Lahaul from Kullu, Kunjum Pass $(4740 \mathrm{~m})$ road to Lahaul from Spiti, Baralacha Pass (5019 m) road to Lahaul from Leh, Kugti Pass (5043 m) partially by road and on foot, and Drati Pass (4725 m) by foot journey from Chaurah-Chamba to Lahaul.

The distinctive features of the valley are snow covered peaks, massive glaciers, view of bleak, sunny, higher mountain ranges and narrow river valleys. The valley represents few prominent lakes such as Chandratal, Surajtal, Sissutal and Neelkant along with many glaciers. Andrew Wilson denoted this valley as a "Valley of Glaciers" [14]. High mountains, water falls, Buddhists Gompas, Hindu Temples and trekking places are some of the attractions for tourists. The inhabitants belong to Hindu and Buddhist community.

The district contains 41 Panchyats. The total area of the district is $13,835 \mathrm{~km}^{2}$, out of which $1,35,369$ hectares are under Forests and 4459 hectares are under cultivation. The whole area of Lahaul is divided into four valleys namely, Pattan Valley, Myar Valley, Todh Valley and Tennan Valley. In the valley soil is more or less loam to sandy loam with gravel. In the vicinity of villages and nearby, denuded slopes are subjected to concentrated year round grazing; hence the soil is equally poor. On the northern aspects, in folds and hollows as also on easier slopes, the soil is fairly deep and fertile for tree growth. It is therefore, the best forests in the valley are on the left bank of the Chanderbhaga River.

Due to melting of snow, the soil from the upper slope is carried down to the lower slopes where the depth of the soil is deeper. At present, soil in this tract is patrtillay protected by the vegetation. The climate of the area is dry temperate to alpine types and has distinct seasons. The summer is rainless due to high mountains. The rainy season receive very less rainfall. The winter season is comparatively a large i.e., from late November to early
April. During this period, heavy snow fall occurs in the Valley.

The Lahaul valley is also known for its unique faunal diversity. Some of the prominent wild animals and birds are Ibex (Capra ibex), Bharal (Psueudois nayaur), Snow Leopard (Panthra uncia), Musk Dear (Moschus chrysogaster), Ghoral, (Nemorhaedus goral), Himalayan Marmot (Marmota bobak), Wild Yak (Bos grunniens), Himalayan Snow Cock (Tetragallus himalayensis), Himalayn Snow Pigean (Columba leuconota), Crow (Corvus caurinus), Chukor (Alectoris chukar), Bar-headed Goose (Anser indicus), Snow Pigeon (Columba leuconota) and Himalayan Snow Cock (Tetraogallus himalayensis).

Man has been utilizing plant resources for various purposes since the time immemorial. The documentation of traditional knowledge would appear to be the "need of the hour" in view of the current demand for herb based products. Documentation serves to ensure the preservation of traditional information for future generations. It is also a step forward in the creation of a database on ethnobotanical notes. An attempt therefore, has been made here to document the indigenous uses of some important medicinal and aromatuic plants of Lahaul; Valley.

\subsection{Surveys and Data Collection}

The Lahaul valley has been surveyed under an adhoc project funded by National Medicinal Plant Boards (NMPB) Govt. of India, New Delhi during 2008-2010 to generate information on indigenous uses of medicinal plants from the inhabitants. Information on medicinal plants was collected through Participatory Rural Appraisal (PRA). After interaction, the inhabitants were interviewed for utilization of medicinal plants and aromatic plants, mode of administration, occurrence in the area, etc. in different valley of the Lahaul valley.

\section{Results}

\subsection{Treatment by Animal Parts}

The amchies keep in their medicine bags animal organs like; dog or wolf tongue, antelope horns, snake flesh rabbit heart and bile of beer and tiger etc. for treatment in eheumatism, epilspsy and pulmonary and bronchial diseases.

\subsection{Treatment with Mineral Water}

Sulphur and mineral springs in Kullu-Manali and Ladhak area are frequently used in the treatment of headache and other diseases of brain. 


\subsection{Puncturing of Veins}

The treatment consists of pricking the patient body with specially needles at certain points. Usually this therapy is uses for treatment of gout, blood and skin disorders.

\subsection{Treatment by Mysticism}

Treatment by Mysticism (Tantra-Mantra) is with influence with stars on human destiny. They treat the patient by looking at the horoscope for their evil and good stars.

\subsection{Other Uses}

\subsubsection{Use of Shilajit as a Single Medicine}

Shilajeet is used as a single medicine in old age, for genel debility and as an approdisiac. The medicine should be taken on an empty stomach with milk or lukeworm water. Peas and pigeons are forbidden in the diet while taking shilajit.

Dose: $8 \mathrm{mg}$ in first week and thereafter $16 \mathrm{mg}$ for $2^{\text {nd }}$, $3^{\text {rd }}$, and $4^{\text {th }}$ week. Then the dose is increased by $2 \mathrm{mg}$ up to 7 weeks and then it should be maintained.

\subsubsection{Other Minerals Used in the Theraphy Are}

- Sulphur;

- Borax;

- Sodium Sulphate;

- Antimoni Sulphate;

- Sodium Bicarbonate;
- Yellow Arsenic;

- Serpentine;

- Quartz;

- Metals and Bhasmas.

\section{Discussion}

The present study reveals that there is an intimate relationship between the inhabitants of Lahaul valley, particularly native people and plants of their surroundings. During field studies, it was noticed that a vast treasure of hidden knowledge is lying with them especially with the old people living in the valley. A wide range of ailments/diseases ranging from common cold \& cough to asthma, bronchitis, liver, stomach, heart, kidneys, and cuts and wounds to snakebites are treated by the traditional healers of the valley (Amchies) with the help of local plant remedies.

In total, 354 species of medicinal and aromatic plants belonging to 208 genera and 76 families were recorded from the Lahaul valley [15-17]. Out of the total 79 plant species of medicinal and aromatic plants belonging to 37 families and 64 genera have been discussed in the present paper which are used to cure more than two diseases (Table 1). The population of Aconitum heterophyllum (Critically engangered), Picrorhiza kurrooa and Rheum emodi (Engangered) and Begenia stracheyi and Rhododendron anthopogon (Vulnerable) according to IUCN categoirization are very low.

Most of the plant species are in the altitudinal ranges

Table 1. Diversity, distribution and indigenous uses of some important medicinal plants and aromatic plants occurring in cold desert area of Lahaul valley.

\begin{tabular}{|c|c|c|c|c|c|}
\hline Taxa/Family & Local name & $\begin{array}{l}\text { Altitudinal range } \\
\qquad(\mathrm{m})\end{array}$ & $\begin{array}{l}\text { Herb/Shru } \\
\text { b/Tree }\end{array}$ & Parts used & Indigenous uses \\
\hline \multicolumn{6}{|l|}{ Alliaceae } \\
\hline Allium carolinianum DC. & Keor, Jimboo & $3300-4000$ & $\mathrm{H}$ & Leaf and bulbs & $\begin{array}{l}\text { Stimulant, diuretic, given with milk after } \\
\text { delivery); Soup making regarding the } \\
\text { treatment of stomach infections. }\end{array}$ \\
\hline Angelica glauca Edgew. & Chaura & $2700-3510$ & $\mathrm{H}$ & Roots & $\begin{array}{l}\text { It is beneficial in restoring kidney heat } \\
\text { and treating anemia, debility, lung dis- } \\
\text { eases, stomach disorders and fluid reten- } \\
\text { sion in the joints. }\end{array}$ \\
\hline Bunium persicum B. Fedtsch & Kalagira & $2760-3700$ & $\mathrm{H}$ & Seeds & $\begin{array}{l}\text { Abdominal pain, cold, cough, fever, loss } \\
\text { of appetite, back pain, liver problems, } \\
\text { dysentery in domestic animals and also } \\
\text { used as condiment. }\end{array}$ \\
\hline Carum carvi L. & $\begin{array}{l}\text { Gonyorog, } \\
\text { Shingu Jeera }\end{array}$ & $2700-3650$ & $\mathrm{H}$ & Seeds & $\begin{array}{l}\text { It is used to alleviate the disorders of the } \\
\text { lungs. Also used in eyes ailments. }\end{array}$ \\
\hline Chaerophyllum aromaticum L. & Shakkara & $3000-3400$ & $\mathrm{H}$ & Roots & $\begin{array}{l}\text { Used against Indigestion; } \\
\text { Roots along with mint leaves are acts as } \\
\text { flavor agent. }\end{array}$ \\
\hline
\end{tabular}


Ferula jaeschkeana (L.) Vatke

Heracleum candicans Wall. ex DC.

Dundu, Raswal

2690 - 3660

$\mathrm{H}$

Rhizomes

Selinum vaginatum (Edgew.) Cl.

Matosal

$2710-3630$

$\mathrm{H}$

Rhizomes

\section{Asteraceae}

Achillea millefolium L.

Arctium lappa L.

Artemisia biennis Willd.

A. dracunculus L.

A. maritima $\mathrm{L}$.

A. nilagarica (Cl.) Pamp.

Cichorium intybus L.

Cousinia thomsonii $\mathrm{Cl}$.

Echinops cornigerus DC.

Inulu racemosa $\mathrm{Hk}$.

Jurinella macrocephala (Royle) Aswal

Senecio graciliflorus (L.) DC.

Sonchus oleraceus L.
Chabu, Shugumentog

$2700-3600$

$3200-3420$

Pichawag

Karkatang,

Khampa

Chamary,

Burtse

Seski, Nyurcha,

Garpeg,

Nyurchi, Sensi

$2600-3800$

$\mathrm{H}$

Chirmara

$2990-3490$

$\mathrm{H}$

\section{Khibsha}

2710

Changchher,

Bacha Chawag, Khibsha

Chawag

$2500-3500$

$\mathrm{H}$

Mano

$2600-3500$

$\mathrm{H}$

Above 3700

$\mathrm{H}$

Zerjum

$3200-3800$

Panu Aag

$2640-3830$
$\mathrm{H}$

Whole Herb

H
Whole herb

Whole herb

Roots

It is used as Carminative, tonic, stimulant, toothache, cough, cold, insect repellent and diaphoretic.

It treats Gastric, burns; burs used for repelling rodents.

Whole herb Used against obesity.

Acts as Carminative for animals, throat infection, toothache and in menstrual cycle.

Tonic used to remove abdominal parasites, anthelmintic, antiseptic, blood purifier, gastric disorder; Edible bunch grass used for storing the boiled water after sprinkling the sattu or roasted barley (thukpa).

Abscess, analgesic, anthelmintic, antiseptic, antispasmodic, asthama, ear complaints, epilepsy, haemostat, headache, menstrual complaints, nervous disease, peptic ulcer, skin disease, sores, stomachache, tonic, vermifuge, wounds.

Used to treat Fever, headache, vomiting, diarrhoea, joint pain, also act as blood purifier.

Cure body pain, swelling due to sprain, diuretic.

Used to cure Cold, cough, promote teeth of infants, fever, urinary trouble, tonic, septic, food poisoning.

It is used to treat Asthma, blood purify, stomach disease, rheumatism, liver complaint, fever, headache.

Roots are Antiseptic, used to cure fever during child birth, laxative, skin eruption); Religious (incense in temples).

Used as Antidote against insect bite, ring worm disease, pussed ear.

Used to treat jaundice and liver complaints. 
Taraxacum officinale Wigg.

Paranbala,

Quanti, Sarkhen

Mentok, Dudhi

$2710-3800$

$\mathrm{H}$

Whole Herb

Betulaceae

Betula utilis D.Don

Bhojpatra, Shag, Bhuj

$3000-4000$

$\mathrm{T}$

Bark and other aerial parts

Curing redness in eyes antiseptic, antiseptic, burns, cuts, contraceptive, ear complaints, hysteria, jaundice, spermicidal, Wounds. tion of the liver, loss of appetite, food poisoning, antibiotic, tonic, blood purifier, hepatitis, migrains, foreheads); Religious; Musical instrument; Temporary tattooing of hands.

\title{
Boraginaceae
}

\author{
Arnebia euchroma Royle ex \\ Benth. \\ Onosma hispida Wall. ex G. Don

\section{Campanulaceae} \\ Codonopsis clematidea \\ (Schrenk) $\mathrm{Cl}$. \\ C. ovata Benth.
}

Ratanjot,

Khomig

Kaume

$3410-3550$

$\begin{array}{ll}\text { Golchokpa } & 2800-3500 \\ \text { Golchokpa } & 3400-3600\end{array}$

H

$\mathrm{H}$

\section{Cannabaceae}

Cannabis sativa $\mathrm{L}$.

Bhang, bang

$2600-3500$

$\mathrm{H}$

Seeds, Leaves and Stem

Churupa

$2900-4000$

$\mathrm{H}$

Sokann, Sanyek

$2500-3550$

$\mathrm{H}$

Aerial part

Cupressaceae
Petada, Shukpa,

$$
\text { Dhup }
$$

$2500-4000$

Sh

Entire herb

Juniperus communis L.

J. polycarpos Boiss.
Shur, Leyur
$2500-4000$
Roots and

leaves

Flower and seeds

laeves

Used as bandage of cuts, headache, fever, liver, kidney, chronic disease of the digestive organs, cure jaundice, inflamma-

Act as Abortifacient, hair tonic, also used to treat blood pressure, backache, headache); dye.

Used as blood purifier, cuts, swells, ulcer, wound); Religious; (lamma people use the pink dye for lamistic ceremonies).

Used to treat Rheumatism, swelling due to sprain, and skin disease.

Medicinal (Oxytoxic, wound).

Used to cure appetite, bowel complaints, bronchitis, cuts, dyspepsia, ear, eye complaints, gonorrhoea, narcotic, piles, skin disorder, skin eruption, cold, cough, convulsions, cramps, epilepsy, laxative, nervine stimulant, paralysis of tongue, sleeping pills Miscellaneous (local shoe: Pula is prepared).

Aerial part Used to treat Cough and lung infections.

Used to treat Gastric disorder, Gall bladder, liver diseases.

It is useful against treating Kidney disorder, malfunctioning of kidney, liver, bladder, heart disease, nervous disorder, oil-from barriers inhaled as vapors, or taken in the form of pills, dropsy mucous discharge, antibiotic for animal, repel flies); Fuel; Religious (smoke purifier, against evil sprits, leaves dipped three times in arak or chang as a mark of celebration).

Oil is used as antibiotic for animal, repel flies, nervous disorder, stomach cramp); Fuel; Timber; Religious (incense, smoke purifier, leaves dipped three times in arak or chang as a mark of celebration, against evil sprits. 


\section{Dioscoreaceae}

Dioscorea deltoidea Wall. ex Kunth

Kinsh

$2490-3000$

$\mathrm{H}$

Tubers

Elaeagnaceae

Hippophae rhamnoides D. Don

H. salicifolia D. Don

Sarla

$3100-3600$

Fruits and bark

\section{Ephedraceae}

Ephedra gerardiana Wall. ex Stapf

Cicer microphyllum Benth.

Fumariaceae

Corydalis govaniana Wall.

\section{Gentianaceae}

Swertia cordata (G. Don) Cl.

\section{Geraniaceae}

Geranium nepalense Sw.

G. pratense L.

\section{Hypericaceae}

Hypericum perforatum L.

\section{Iridaceae}

Iris kemaonensis D. Don ex Royle

Juglandaceae

Juglans regia L.
Kiok, Buchchur,

Chhe,

Somlata

$2500-3900$

Banyarts,

Vana-nyarcha, Chiri

$2600-3800$
$\mathrm{H}$

Fruits and bark

$2700-3600 \quad \mathrm{H} \quad$ Whole herb

$\begin{array}{llll}\text { Laljari, } & 2900-4000 & \text { H } & \text { Roots }\end{array}$

$2800-4000 \quad \mathrm{H} \quad$ Whole herb

$$
\text { Praynal }
$$

$3000-3900$

$\mathrm{H}$

Whole herb

Laeves, Branches and

It is beneficial in treating diseases of the lungs, blood coagulation and blood cysts.

Used ty treat Cuts, ulcer, wounds, cough, fever, dandruff of hairs and skin disease); Edible; Fuel; Fodder; Small timber; Agricultural tools.

It is a rejuvenating agent and is useful against the treatment of haemorrhage, gall bladder, liver, spleen and all kinds of initial and chronic fevers.

Used to cure mouth disease tongue infection, jaundice.

Used against excess formation of impure blood. Also used for drying up excess pus formation in lungs and visceral organs. Herb is also used to heal ruptured wounds and fractured bones.

Used in treatment of hot disorders of the gall bladder.

Used to treat Cuts, jaundice, toothache, ulcer, wounds and stomach complaints.

Used as Naksur, black dye, stomach trouble, jaundice, gastric disorder.

Used in inhancement of immunity, cures malarial fever, anti-depressant, anti-tumourous, anti-cancerous, anti-viral.

Medicinal (Epilepsy, fever, toothache).

Fruit-coat \& bark is useful for teeth cleaning, skin diseases, anthelmintic, astringent, toothache, fungicide, insecticides.

\section{Lamiaceae}

Ajuga bracteosa Wall. ex Benth.

Karku, Neelkanthi

$2600-3200$

Whole herb

Used to treat Malarial fever and tonic for gastric problems.

Mentha longifolia (L.) Huds.

Takchi, Marini, Madaen

$2700-3600$

Whole herb

Used as carminative, digestive, on wound to kill maggots.

Origanum vulgare L. 
Thymus linearis Benth. Kochi masha $2730-3800 \quad$ H $\quad$ Whole herb

Polygonatum cirrhifolium

(Wall.) Royle

P. verticillatum $\mathrm{L}$.

Malvaceae

Malva sylvestris L.

M. verticillata L.

Orchidaceae

Dactylorhiza hatagirea (D. Don.) Soo

Hathpanja

$3000-3400$

$\mathrm{H}$

Tubers

\section{Oxalidaceae}

Oxalis corniculata $\mathrm{L}$.

Paparveraceae

Meconopsis aculeata Royle

Chharbongcha, Chharmen

$3200-4000$

$\mathrm{H}$

Whole herb

Plantaginaceae

Plantago depressa Willd.

P. major L.

Karecha

$2600-3450$

$\mathrm{H}$

Podophyllaceae

Podophyllum hexandrum Royle

Bankakri,

Omo-shey,

Braburchoi,

$2500-3700$

Pindiyali

\section{Polygonaceae}

Bistorta affinis Greene
Chunru, Kapad
$2700-4000$
Used as Antifungal, antibacterial, pain reliever during childbirth to mother, whooping cough, epilepsy, skin eruption, reduce excessive bile secretion, juice, alopecia or hair loss, spices phlegm counter spasmodic pains, stomach complaint, cold, toothache, kill hookworms, liver compliant, heating effect);

It restores body strength and is useful in the treatment of pain in kidneys and waist region, fluid retension in joints and impotency

Used to cure Appetite, Nervine tonic, kidney trouble and also restores body strength

Used against treatment of Stomach cramp and whooping cough

It is used to treat dropsy, thrists, diarrhea, infected sores and dilates all vessel in the body.

Used as Antibiotic, wound healing, bone fracture, cough, cold, cuts, sexual disability, rheumatism, blood purifier, tonic, many ayurvedic and unani medicine preparations

Used to cure Appetite, corns, cuts, dysantery, fever, jaundice, rickets, scurvey, stomachache, swelling, wart, cataract, conjunctivitis

It is effective against the disorder of lungs, liver and inflammation.

It stops diarrhea and also beneficial in treating fevers.

Used against the treatment of Fever, cough, gastric disorders and other stomach diseases

It is used for gyaecological diseases like menstrual irregularity, diseases of uterus. Also improves blood circulation, helps in delivery.

Cures diarrhoea, check flatulence and also check dysentery 


\author{
Rheum australe Spreng.

\section{Primulaceae} \\ Androsace rotundifolia Hardw. \\ Primula denticulata Sm. \\ P. rosea Royle
}

Archo

$3015-3910$

Napchati

$2500-3700$

$\mathrm{H}$

Entire herb

Zigsolo marpo

$2730-3400$

$\mathrm{H}$

$3100-3840$

$3510-4000$

H

Entire herb

$\mathrm{H}$

Entire herb

\section{Ranunculaceae}

Aconitum heterophyllum Wall. ex Royle

Bonga, Atees

$$
\text { Boa }
$$

$2900-3600$

A. violaceum Jacq. ex Stapf

Dudatees, Jhimba

$3600-4000$

Chutrak

$3100-3560$

$\mathrm{H}$

Anemone rivularis Buch.-Ham.

Kasturi-chey,

Delphinium cashmerianum Royle

R. hirtellus D. Don

Thalictrum minus L.

Rosaceae

Fragaria vesca var. nubicola $\mathrm{L}$.

Palla

$2500-4000$

\section{Rubiaceae}

Rubia cordifolia L.

\section{Saxifragaceae}

Bergenia ligulata Haw. Sternb.

Silpayi

$3400-4000$

H

Silpayi

$3300-4000$

$\mathrm{H}$
Entire herb

Rt, Lf

It purges epidemic diseases and also beneficial in treating indigestion and flatulence.

Helps in treating Boils, colic, cooling, diuretic, dymenorrhoea, purgative, scurvey, swelling of muscle, stomachache.

Reduces excess serous fluid, fever, wound in the body and sudden swelling.

It is useful in treating wounds, psoriasis and warts.

It is useful to cure muscular pain.

It is an antitode against snake and scorpion bite and treats infectious fever. Also useful in treating intestine infections.

Used to cure cough,

gastrointestinal complaints, renal pain, rheumatism and stomachache.

Restores digestive heat of the stomach. Also useful in treating indigestion, tumors of cold nature, helas infected wounds.

It ius used against frequent occurrence of common cold and feverb due to poisoning, helps to cure sking deseases.

It stops diarrohaea, dries pus of wounds and useful in treatment of lice-infestation.

Used against inflammation, turbid fever, unripe fever and diffused fever.

It reduces ous accumulated in the lungs and chest and also helps in treatment of inflammation of nerves.

It is effective against blood related problems, fever diffused from the kidneys and intestinal fevers.

Used against Asthma, boils, cuts, wounds, Roots and burns, fever, liver complaints, ophthalmia, leaves piles, thirst, kidney stones, urine complaints and diarrhoea of cattles.

Cures Kidney stone, poultice, stiff joint, diuretic, antiscorbutic, astringent, fever, opthalmia, tonic, cuts, wounds); Edible.

It is useful in treating liver and gall bladder problems, excessive seminal discharge, oedema and hangover. 


\section{Picrorhiza kurrooa Royle ex Benth.}

Karu

$3400-4000$

$\mathrm{H}$

Kolomasta,

Verbascum thapsus L. Jawarna Loudi,
Tombru, Tamaku

$2500-3900$

$\mathrm{H}$

\section{Solanaceae}

Hyoscyamus niger $\mathrm{L}$.

Bazerbangh

$2600-3630$
It is useful in treating Anemia, arthritis, asthma, bitter tonic, cardiotonic, cold, dyspepsia, diarrhoea, influenz, diuretic, fever, hepato protective, indigenous system of medicine, jaundice, liver trouble, stomach, laxative, pure circulation blood, neck pain, internal wound, large dose ascathritic.

It is useful in curing Asthma, cough, diarrhoea, dyesentry of sheep, poultice, skin disease, narcotic, fish poisoning, ear infection, dye.

It subsides pains cused due to pathogen diseases, toothache, pharyngitis and also used in treating malignant ulcers.

\section{PTERIDOPHYTES}

Equisetaceae

Equisetum arvense L.
Khin
$\mathrm{H}$
It acts as Diuretic haemostatic, properlicAshes of plants kidney, dropsy gravel affection, acidity, dyspepsia.

*H-herb; Sh-Shrub; T-Tree.

from 2800 to $3800 \mathrm{~m}$ above the mean sea level. It was observed that the developmental activities like; contruction of roads, dams and hydropower units had brought rapid change in local environment, old culture, mindset of the native people and also threatened to existing flora and flauna of the valley.

The occurrence of near endemic, endemic, critically endangered, endangered, vulnerable, near threatened and threatened species indicated high anthropogenic pressure and that area has high conservation value. Most of these species are commercially viable. Mass reproduction for ex-situ conservation and to ensure availability of quality planting material for cultivation, together with education and awareness programmes for large-scale cultivation are suggested. The old people still says that the superstition is the best way to conserve this valuable wealth.

\section{Acknowledgements}

Help of forest officials of Lahaul valley is duly acknowledged. Thanks are due to the inhabitants for sharing important information regarding the use of plants. The authors are grateful to National Medicinal Plant Board, Govt. of India for providing financial assistance through a project.

\section{References}

[1] N. Bahar, "Some Medicinal Plants of Cold Desert," Indian Forester, Vol. 128, No. 4, 2002, pp. 465-469.

[2] P. P. Dhyani and C. P. Kala, "Current Research on Me- dicinal Plants: Five Lesser Unknown but Valuable Aspects," Current science, Vol. 88, No. 3, 2005, p. 335.

[3] S. S. Samant, U. Dhar and L. M. S. Palni, "Medicinal Plants of Indian Himalaya: Diversity Distribution Potential Values," Gyanodaya Prakashan, Nainital, 1998.

[4] S. S. Samant and L. M. S. Palni, "Diversity, Distribution and Indigenous Uses of Essential Oil Yielding Plants of Indian Himalayan Region," Journal of Medicinal \& Aromatic Plant Sciences, Vol. 22, 2000, pp. 671-684.

[5] S. S. Samant, U. Dhar and L. M. S. Palni, "Himalayan Medicinal Plants: Potential and Prospects," Gyanodaya Prakashan, Nainital, 2001.

[6] S. Blangy and H. Mehta, "Ecotourisim and Ecological Restoration," Journal of Nature Conservation, Vol. 14, No. 3-4, 2006, pp. 233-236. doi:10.1016/j.jnc.2006.05.009

[7] N. Myers, R. A. Muttermeier, C. A. Muttermeier, A. B. G. da Fonseca and J. Kent, "Biodiversity Hotspots for Conservation Priorities," Nature, Vol. 403, 2000, pp. 853-858. doi: $10.1038 / 35002501$

[8] B. S. Aswal and B. N. Mehrotra, "Ethnobotanical Studies on the Flora of Lahaul Valley (North-West Himalaya)," In: M. R. Sharma and B. K. Gupta, Eds., Recent Advances in Plant Sciences, Bishen Singh and Mahendra Pal Singh, Dehradun, 1987, pp. 116-130.

[9] S. K. Sood, R. Nath and D. C. Kalia, "Ethnobotany of Cold Desert Tribes of Lahoul-Spiti (North West Himalaya)," Deep Publications, New Delhi, 2001.

[10] C. P. Kala, "Medicinal Plants of Indian Trans-Himalaya," Bishen Singh Mahendra Pal Singh, Dehradun, 2003.

[11] C. P. Kala, "Medicinal Plants of the High Altitude Cold Desert in India: Diversity, Distribution and Traditional 
Uses," International Journal of Biodiversity Science and Management, Vol. 2, No. 1, 2006, pp. 43-56. doi:10.1080/17451590609618098

[12] S. S. Samant, S. Pant, M. Singh, M. Lal, A. Singh, A. Sharma and S. Bhandari, "Diversity, Distribution Pattern, Indigenous Uses and Conservation Prioritization of Medicinal Plants of Himachal Pradesh, India," International Journal of Biodiversity Science and Management, Vol. 3, No. 4, 2007, pp. 234-251. doi:10.1080/17451590709618177

[13] G. S. Singh, J. C. Kuniyal and S. C. R. Vishvakarma, "Agrobiodiversity of Cold Desert of Lahaul Valley: Present Scenerio," Everyman's Science, Vol. 38, No. 6, 2004, pp. 331-334.

[14] B. S. Aswal and B. N. Mehrotra, "Flora of Lahaul-Spiti (a Cold Desert in North-West Himalaya)," Bishen Singh and Mahendra Pal Singh, Dehradun, 1994.
[15] A. Singh, L. Manohar and S. S. Samant, "Diversitry, Indigenous Uses and Conservation of Medicinal Plants in Lahaul Valley, Proposed Cold Desert Biosphere Reserve, India," International Journal of Bidiversity Science and Managemnent, Vol. 5, No. 3, 2009, pp. 132-154.

[16] N. S. Chauhan, "Endangered Ayurvedic Pharmacopoeial Plant Resources of H. P.," In: P. Kaushik, Ed., Indigenous Medicinal Plants, Today and Tomorrows Printers and Publishers, New Delhi, 1988, pp. 187-198.

[17] S. S. Samant, J. S. Butola and A. Sharma, "Assessment of Diversity, Distribution, Conservation Status and Preparation of Management Plan for Medicinal Plants in the Catchment Area of Parbati Hydroelectric Project StageIII in Northwestern Himalaya," Journal of Mountain Science, Vol. 4, No. 1, 2007, pp. 34-56. doi:10.1007/s11629-007-0034-3 